\title{
A Multidimensional Approach of Oxidation in Food Emulsions
}

Genot, C..$^{1}$, Viau, M. ${ }^{1}$, Villière A. ${ }^{1}$, Rampon V. ${ }^{1}$, Andersen, ML. ${ }^{2}$, Skibsted, LH $^{2}$, Meynier, A. ${ }^{1}$ (1) : INRA, Unité Biopolymères, Interactions, Assemblages, BP71627 44316 Nantes Cedex3 France claude.genot@,nantes.inra.fr

(2) Department of Dairy and Food Science, KVL, DK-1958 Frederiksberg C, Denmark

\begin{abstract}
In foods, unsaturated lipids are often present as dispersed phases, that favours their oxidation, limiting extended shelf-life of unsaturated lipid-enriched products. Proteins, that are present in the aqueous phase or participate to the stabilization of the dispersions also intervene in the oxidation process. Our work was aimed at investigating oxidation of oil-in-water emulsions stabilized by proteins. Model emulsions were aged at $50^{\circ} \mathrm{C}$ in sealed tubes. Oxidation was followed by complementary methods allowing evaluation of substrate consumption and formation of free radicals, primary and secondary lipid oxidation products and lipid oxidationprotein reaction products. The odour and the physical stability of the emulsions were also evaluated. According to chelating and free radical scavenging properties of the protein emulsifier, the availability of the metal ions in the medium or the initial $\mathrm{pH}$ of the aqueous phase lipid oxidation was significantly delayed or promoted. Differences in the relative compositions of the volatile fraction indicated that oxidation mechanism were modulated by emulsifier and $\mathrm{pH}$ of the aqueous phase. The reaction continued after total consumption of oxygen leading to continuous formation of volatile compounds, lipid-protein fluorescent interaction products and changes in the odour of the emulsions. Investigation of the effect of emulsion droplet size on oxidation gave different pictures according to the marker. These results, combined with others of the literature, highlight the need to consider the oxidation of multiphase food systems as a multidimensional phenomenon that involve all food components and phases and should be investigated as different time and space scales.
\end{abstract}

Key-words : lipid, unsaturated fatty acids, oxidation, emulsion, interface, protein, partition, interaction

\section{Introduction}

Worldwide nutritional recommendations insist of the need to insure a well-balanced lipid supply [1]. It is recommended to increase the unsaturated/saturated fatty acids ratio in the diet. However, increasing unsaturated lipids in foods also signifies increasing hazards due to oxidative degradation. In fact, lipid oxidation remains, more than ever, a major cause of sensory and nutritional deterioration of foods [2-5]. It is also for food processors a main cause of economical losses. In many foods, lipids are present in the form of oil or fat droplets dispersed in a continuous aqueous phase [6,7]. These oil-in-water emulsions are stabilized by an interface that consists, among other compounds, of adsorbed protein molecules. Adsorbed and non-adsorbed proteins can react with primary and secondary products of lipid oxidation, giving rise to newly-formed compounds [8]. They may also influence the rate and extent of lipid oxidation. Other compounds, present in the oil or in the aqueous phase of the emulsions are also be targeted by oxidative degradation. It is the case for antioxidants such as tocopherols or phenolic compounds. These healthy compounds, naturally present in the raw materials, contribute to the protection of the polyunsaturated fatty molecules owing to their sacrificial action. In contrast, metal ions, that are naturally present in raw materials or are gained during processing are often primary initiators of oxidation $[2,6]$. Their efficiency to induce oxidation deeply depends on their location and interactions in the food matrix. In these conditions, an thorough understanding of the factors that influence lipid oxidation in foods is 
required to guarantee product quality, extended shelf-life, better-designed processing operations and optimized use of additives.

The objective of our work was to sort of the factors, including protein emulsifiers, $\mathrm{pH}$, metal availability and oil droplet size, that intervene in the development of lipid oxidation

\section{Material and methods}

The influence of the nature of the emulsifier and of the physicochemistry of the aqueous phase on oxidation was studied in $30 \%(\mathrm{p} / \mathrm{p})$ oil-in-water model emulsions [9]. Sunflower oilin-water emulsions stabilized by protein (bovine serum albumin : BSA or sodium caseinate : NaCas) or Tween 20 were aged at $50^{\circ} \mathrm{C}$ in sealed tubes [10].

The physical stability of the emulsions was evaluated from measurements of the size distribution of the oil droplets with a laser granulometer.

As lipid oxidation is a train of chain reactions, the reaction was characterized with methods making it possible to evaluate oxygen consumption, the formation of primary products of oxidation (conjugated dienes : CD), the development of volatile products secondary products of oxidation and that of oxidized lipid/amino acid reaction products. Also the degradation of the protein was evaluated from front-surface measurements of fluorescence of the protein. The kinetics were measured in the closed vessels at time intervals selected with the purpose of evaluating the early stage of oxidation development as well as the latest stages. Consumption of substrates was evaluated by measurement of oxygen uptake in the headspace of the emulsions by gas chromatography (GC) with a thermal conductivity detector [10]. Protein alteration was appreciated from the decrease of tryptophan fluorescence measured directly on the emulsions in front-face mode [11]. Formation of free radicals was followed by Electron Spin Resonance in the presence of a spin probe : N-ter-butyl- $\alpha$-phenylnitrone [12]. Formation of primary products of oxidation was evaluated by spectrophotometric measurement of conjugated dienes [13]. Volatile compounds were quantified (19 volatile compounds identified and quantified) using solid phase microextraction paired with GC [9]. Formation of lipid oxidation-protein fluorescent reaction products was followed in the emulsions by frontface fluorescence spectroscopy [14]. Reactivity of the proteins towards aldehydes issued from lipid oxidation was also appreciated with several spectroscopic or separative methods (RPHPLC, SDS-PAGE). Finally, sensory profile of the odour of the emulsions was determined with a trained panel (9, Villière et al., submitted to EJLST).

\section{Results and discussion}

The results demonstrate that, as compared to bovine serum albumin, sodium caseinate significantly delayed or promoted lipid oxidation according to the availability of the metal ions [10]. This results from iron-binding and free-radical scavenging properties of sodium caseinate as shown from iron binding and ESR experiments [9,15]. Oxidation of BSA stabilised emulsions was clearly favoured when the initial $\mathrm{pH}$ of the aqueous phase was equal to 4.0 as compared to initial $\mathrm{pH}$ of 6.5 , probably due to changes in the physicochemical properties and reactivity of the protein, either at the interface or in the aqueous phase [9]. Changes in the relative composition of the volatile fraction indicate that oxidation kinetics and reaction mechanisms were affected by emulsifier and $\mathrm{pH}$ of the aqueous phase. The changes in the amounts and proportions of volatiles during oxidation were associated with changes in the odour of the emulsions that could not be directly predicted from produced amounts of one volatile compounds or another. The chemical changes affecting the lipid and protein fractions were found to continue well after total consumption of initially available oxygen $[11,14]$. The free radicals and primary products of oxidation produced during the early stages of oxidation progressively decomposed or reacted with other compounds leading to progressive alteration of the emulsions and continuous formation of both volatile and fluorescent oxidation 
compounds. As viewed by UV-Vis, circular dichroism, fluorescence spectra, RP-HPLC chromatogram and gel electrophoresis, the fixation of the unsaturated aldehydes : 2-hexenal and 2,4-hexadienal by protein in model solutions led to changes in the protein structure, in the environment of tryptophanyl residues, formation of fluorescent compounds and of covalent protein dimers, not due to disulfure bonds $[16,17]$.

Influence of droplet size, or interfacial area, on oxidation of emulsions stabilized by BSA gave different pictures according to the marker. Oxygen consumption and formation of conjugated were not highly affected by the droplet size of the emulsions $[13,18]$. Results concerning volatile compounds were contrasted as different behaviours were observed with not clear rule according to either the volatile chemical function of formation mechanism [9]. In contrast, smaller droplet size and larger interfacial area resulted clearly in a faster decrease of protein fluorescence [11,14]. Fourth derivative fluorescence spectra showed that the changes probably targeted Trp residues of adsorbed proteins, but located in a hydrophilic environment. Formation of fluorescent pigments resulting from reactions of oxidised lipid with protein was favoured with the smaller droplet size emulsions and also at acid $\mathrm{pH}$.

These results, combined with others of the literature [2,3,6-8], highlight the need to consider the oxidation of multiphase food systems as a multidimensional phenomenon that involve all food components and phases and should be investigated as different time and space scales.

\section{Acknowledgements}

Nathalie Moreau, Benoît Bousseau, Isabelle Bronnec, L. Li Yuet Hee and Laurent Le Thuaut are greatly acknowledged for their active participation to this work.

INRA et région Pays de la Loire funded this work as part VANAM program and for A. Villière's thesis grant.

Access to the LMC infrastructure (Levnedsmiddelcentret, Centre for Advanced Food Studies, KVL, Denmark) was made possible through the support of the EU Access to Research Infrastructures part of the Improving Human Potential Programme.

\section{Literature cited}

1- Martin A (2001). Apports nutritionnels conseillés pour la population française, Technique et documentation, Lavoisier Paris.

2- Frankel E.N. (2005). Lipid oxidation. Bridgwater: The Oily Press LTD.

3- Pokorny J (2003). Problème de stabilité des produits alimentaires liés à la présence des lipides. In: Lipides et corps gras alimentaires. Graille J. Ed.: Technique et documentation, Lavoisier, Paris, 147-187.

4- Kubow S. (1991). Routes of formation and toxic consequences of lipid oxidation products in foods. Free Radical Biology and Medicine, 12, 63-81.

5- Riemersma R.A. (2002). Analysis and possible significance of oxidised lipids in food.

European Journal of Lipid Science and Technology, 104, 419-420.

6-McClements DJ., Decker EA (2000). Lipid oxidation in oil-in-water emulsions : impact of molecular environment on chemical reactions in heterogeneous food systems. Journal of Food Science, 65, 1270-1282.

7- Genot C., Meynier A., Riaublanc A. (2003) Lipid oxidation in emulsions. In Kamal-Eldin, A., Lipid Oxidation Pathways AOCS Press (Champaign, IL, USA). pp. 190-244.

8- Genot C., Meynier A., Riaublanc A., Chobert J. M. (2003), Protein alterations due to lipid oxidation in multiphase systems. In Lipid Oxidation Pathways. Ch. 9; Kamal-Eldin A. Ed., AOCS Press pub., Champaign, IL, USA; pps: 265-292.

9- Villière A. (2005) Approche physico-chimique et sensorielle de l'oxydation des lipides dans des émulsions stabilisées par des protéines. Thèse de Doctorat; Discipline : Sciences Agro-Alimentaires - Université de Nantes - 272 pages 
10- Villière A., Viau M., Bronnec I., Moreau N., Genot, C. (2005) Oxidative stability of bovine serum albumin- and sodium caseinate-stabilized emulsions depends on metal availability. J. Agric. Food Chem. 53, 1514-1520.

11- Rampon, V., Lethuaut, L., Mouhous-Riou, N. \& Genot, C. (2001). Interface characterization and aging of bovine serum albumin stabilized oil-in-water emulsions as revealed by front-surface fluorescence. J. Agric. Food Chem., 49(8), 4046-4051.

12- Thomsen, M.K., Kristensen, D. \& Skibsted, L.H. (2000) Electron spin resonance spectroscopy for determination of oxidative stability of food lipids. J. Amer. Oil Chem. Soc., 77, 725-730.

13- Lethuaut, L., Métro, F. \& Genot, C. (2002). Effect of droplet size on lipid oxidation rates of oil-in-water emulsions stabilized by protein. J. Amer. Oil Chem. Soc., 79(5), 425-530.

14- Rampon, V., Mouhous-Riou, N. \& Genot, C. (2002). Protein modifications at the interface during short-term oxidation of emulsions as revealed by front-surface fluorescence. In Anton, M., Recent research developments in agricultural \& food chemistry. Food Emulsions and Dispersions; Research Singpost (Trivandrum, India). pp. 93-102.

15- Villière, A., Genot, C. (2004): Interactions protéines-métaux et stabilité à l'oxydation d'émulsions stabilisées par des protéines. Agoral, Nantes. 30 novembre- $1^{\text {er }}$ décembre. Lavoisier Tec et Doc, pp. 32-39.

16-Meynier A., Rampon V., Dalgalarrondo M., Genot C. (2004), Hexanal and t-2-hexenal form covalent bonds with whey proteins and sodium caseinate in aqueous solution. Int. Dairy J., 14 (8), 681-690.

17- Li Yuet Hee M. L., Dalgalarondo M., Rogniaux, H., Viau, M. \& Genot, C. (2004). Structural and chemical modifications of $\beta$-lactoglobulin induced by aldehydes. Czech J. Food Sci. 22, Special Issue, ISSN 1212-1800, 154.

18- Genot, C., Viau, M., Villière, A., Bronnec, I., Lethuaut, L., Brossard, C. (2002): Effect of droplet size on oxidation and release of volatiles in protein-stabilised food emulsions. $3^{\text {ème }}$ congrès mondial de l'émulsion "Emulsion 2002", Lyon. 24-27 Septembre. CD Rom 4-B104.7. ISBN: 2-86411-151-9 